\title{
PEMBELAJARAN ASAM BASA MENGGUNAKAN LKS BERBASIS LEARNING CYCLE 7E BERBANTUAN WEBLOG UNTUK MELATIH KETERAMPILAN BERPIKIR KRITIS SISWA
}

\author{
Miokti Yessi \\ Guru SMA Negeri 7 Palangka Raya \\ e-mail: yessikimia86@gmail.com
}

\begin{abstract}
ABSTRAK
Penelitian ini bertujuan untuk memperoleh gambaran tentang pembelajaran learning cycle 7E (LC 7E) berbantuan weblog pada materi asam basa dalam melatih dan meningkatkan keterampilan berpikir kritis siswa. Penelitian dilakukan dengan menggunakan metode quasi eksperiment dengan desain one group pretest-posttest only. Sampel dalam penelitian ini adalah siswa kelas XI IPA pada salah satu SMA di Kota Palangka Raya. Pengumpulan data dilakukan dengan memberikan pre-test dan post-test untuk mengukur peningkatan keterampilan berpikir kritis siswa. Data hasil pre-test dan post-test kemudian dihitung gain score (Hake, 1998) untuk masing-masing indikator. Hasil penelitian menunjukkan bahwa skor rata-rata gain yang dinormalisasi $<\mathrm{g}>$ keterampilan berpikir kritis evaluasi 0,76 dengan kriteria tinggi dan penjelasan 0,76 dengan kriteria tinggi. Sehingga dapat disimpulkan bahwa pembelajaran asam basa dengan LC 7E berbantuan weblog secara signifikan dapat melatih keterampilan berpikir kritis siswa.
\end{abstract}

Kata kunci: learning cycle 7E, weblog, keterampilan berpikir kritis, asam basa

\section{PENDAHULUAN}

Seiring dengan perkembangan zaman dan era globalisasi yang ditandai dengan pesatnya produk dan pemanfaatan teknologi informasi, maka konsepsi penyelenggara pembelajaran telah bergeser pada upaya perwujudan pembelajaran yang modern. Inovasi pembelajaran semakin pesat terutama pemanfaatan pembelajaran berbasis teknologi informasi dan komunikasi, terutama di abad 21 sekarang ini yang semakin pesat perkembangan teknologi. Abad ke-21 ditandai sebagai abad keterbukaan atau abad globalisasi, artinya kehidupan manusia pada abad ke-21 mengalami perubahan-perubahan yang fundamental yang berbeda dengan tata kehidupan dalam abad sebelumnya. Dikatakan abad ke-21 adalah abad yang meminta kualitas dalam segala usaha dan hasil kerja manusia. Dengan sendirinya abad ke21 meminta sumberdaya manusia yang berkualitas, yang dihasilkan oleh lembaga-lembaga yang dikelola secara profesional sehingga membuahkan hasil unggulan. Tuntutan-tuntutan yang serba baru tersebut meminta berbagai terobosan dalam berfikir, penyusunan konsep, dan tindakan-tindakan.

Abad ke-21 juga dikenal dengan masa pengetahuan (knowledge age), dalam era ini, semua alternatif upaya pemenuhan kebutuhan hidup dalam berbagai konteks lebih berbasis pengetahuan. Upaya pemenuhan kebutuhan bidang pendidikan berbasis pengetahuan (knowledge based education), pengembangan ekonomi 
berbasis pengetahuan (knowledge based economic), pengembangan dan pemberdayaan masyarakat berbasis pengetahuan (knowledge based social empowering), dan pengembangan dalam bidang industri pun berbasis pengetahuan (knowledge based industry) (Mukhadis, 2013:115). Di abad ke 21 ini, pendidikan menjadi semakin penting untuk menjamin peserta didik memiliki keterampilan belajar dan berinovasi, keterampilan menggunakan teknologi dan media informasi, serta dapat bekerja, dan bertahan dengan menggunakan keterampilan untuk hidup (life skills).

Tuntutan perubahan mindset manusia abad 21 yang nantinya akan membentuk insan yang harus memiliki pengetahuan analitis (analytical knowledge), keterampilan dan karakter yang mumpuni dalam menghadapi persaingan dunia kerja harus dibentuk sejak awal dalam ranah pendidikan formal. Perubahan paradigma pembelajaran dalam pendidikan formal merupakan keharusan jika tidak ingin tertindas oleh perubahan zaman global. P21 (Partnership for 21st Century Learning) mengembangkan framework pembelajaran di abad 21 yang menuntut peserta didik untuk memiliki keterampilan, pengetahuan dan kemampuan di bidang teknologi, media dan informasi, keterampilan pembelajaran dan inovasi serta keterampilan hidup dan karir (P21, 2015). Framework ini juga menjelaskan tentang keterampilan, pengetahuan dan keahlian yang harus dikuasai agar siswa dapat sukses dalam kehidupan dan pekerjaannya.

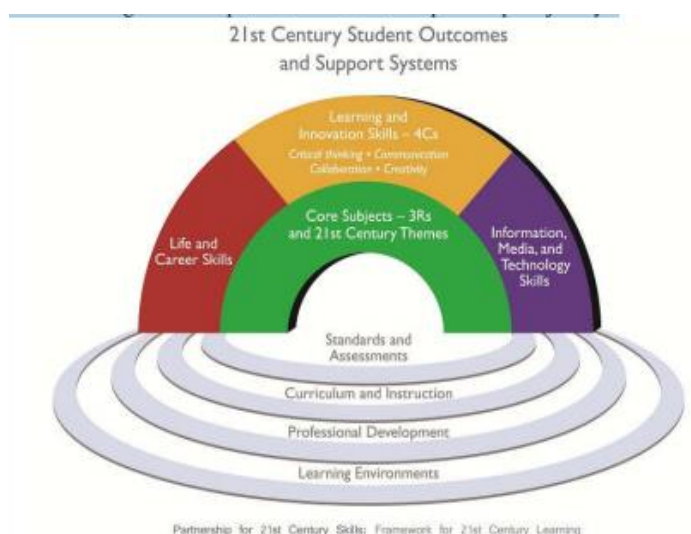

Gambar 1. Framework Pembelajaran Abad ke-21

Kemdikbud merumuskan bahwa paradigma pembelajaran abad 21 dan pembelajaran 4.0 menekankan pada kemampuan peserta didik dalam mencari tahu dari berbagai sumber, merumuskan permasalahan, literasi teknologi, berpikir analitis dan kerjasama serta berkolaborasi dalam menyelesaikan masalah (Litbang Kemdikbud, 2013). Adapun penjelasan mengenai framework pembelajaran abad ke-21 menurut (BSNP, 2010) adalah sebagai berikut: (a) kemampuan berpikir kritis dan pemecahan masalah (Critical-Thinking and ProblemSolving Skills), mampu berfikir secara kritis, lateral, dan sistemik, terutama dalam konteks pemecahan masalah; (b) kemampuan berkomunikasi dan bekerjasama (Communication and Collaboration Skills), mampu berkomunikasi dan berkolaborasi secara efektif dengan berbagai pihak; (c) kemampuan mencipta dan membaharui (Creativity and Innovation Skills), mampu mengembangkan kreativitas yang dimilikinya untuk menghasilkan berbagai terobosan yang inovatif; (d) Literasi teknologi informasi dan komunikasi (Information and Communications Technology Literacy), mampu memanfaatkan teknologi informasi dan komunikasi untuk 
meningkatkan kinerja dan aktivitas sehari-hari; (e) kemampuan belajar kontekstual (Contextual Learning Skills), mampu menjalani aktivitas pembelajaran mandiri yang kontekstual sebagai bagian dari pengembangan pribadi, dan (f) kemampuan informasi dan literasi media, mampu memahami dan menggunakan berbagai media komunikasi untuk menyampaikan beragam gagasan dan melaksanakan aktivitas kolaborasi serta interaksi dengan beragam pihak.

Pergeseran paradigma belajar abad 21 disajikan pada Tabel 1. Tabel 1 menunjukkan pergeseran paradigma belajar abad 21 yang berdasarkan ciri abad 21 dan model pembelajaran yang harus dilakukan. Pergeseran paradigma pendidikan abad 21 . Informasi, komputasi, otomasi, dan komunikasi merupakan empat komponen yang disampaikan Kementrian Pendidikan dan Kebudayaan sebagai ciri dari pendidikan abad 21 yang menyebabkan terjadinya pergeseran paradigma dalam pembelajaran. Alihalih literasi informasi, keterampilan komputer, pemanfaatan teknologi informasi dan komunikasi dalam proses komunikasi serta keterampilan komunikasi menjadi sejumlah kemampuan yang harus dikuasai oleh seorang guru saat ini. Paradigma pembelajaran abad 21 dalam menghadapi era revolusi industri 4.0 memerlukan literasi baru yaitu literasi data, literasi teknologi dan literasi manusia. Hal ini dapat terlaksana dalam pembelajaran dengan menerapkan teknologi dalam kegiatan belajar termasuk pemanfaatan weblog dalam membantu proses belajar mengajar.

Tabel 1. Pergeseran Paradigma Belajar Abad 21

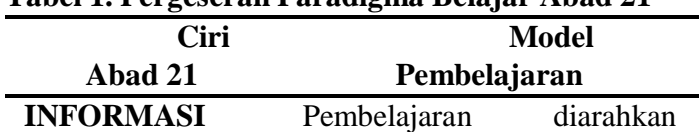

\begin{tabular}{ll}
\hline $\begin{array}{l}\text { Tersedia di mana } \\
\text { saja, kapan saja }\end{array}$ & $\begin{array}{l}\text { untuk mendorong peserta } \\
\text { didik mencari tahu dan } \\
\text { berbagi dan berbagi sumber } \\
\text { observasi bukan diberi tahu }\end{array}$ \\
KOMPUTASI & $\begin{array}{l}\text { Pembelajaran diarahkan } \\
\text { untuk mampu merumuskan }\end{array}$ \\
$\begin{array}{l}\text { Lebih cepat } \\
\text { memakai mesin }\end{array}$ & $\begin{array}{l}\text { manyah (bertanya), bukan } \\
\text { masalah (menjawab) }\end{array}$ \\
OTOMASI & $\begin{array}{l}\text { Pembelajaran diarahkan } \\
\text { untuk melatih berfikir analitis }\end{array}$ \\
Menjangkau & (pengambilan keputusan) \\
semua & bukan berfikir mekanistis \\
pekerjaan rutin & (rutin) menan \\
KOMUNIKASI & $\begin{array}{l}\text { Pembelajaran menankan } \\
\text { pentingnya } \\
\text { kerjasama/kolaborasi dalam }\end{array}$ \\
kemana saja & menyelesaikan masalah. \\
\hline (Litbang Kemdikbud: 2013 )
\end{tabular}

Keterampilan abad 21 yang paling penting diantaranya adalah keterampilan berpikir kritis. Berpikir kritis merupakan aspek penting dan topik yang vital dalam pendidikan modern sehingga para pendidik tertarik untuk mengembangkan berpikir kritis kepada siswa. Berpikir kritis sebagai salah satu proses berpikir tingkat tinggi dapat digunakan dalam pembentukan sistem konseptual IPA peserta didik, sehingga merupakan salah satu proses berpikir konseptual tingkat tinggi (Liliasari, 2002). Keterampilan berpikir kritis perlu dikembangkan dalam diri siswa karena melalui keterampilan berpikir kritis, siswa dapat lebih mudah memahami konsep, peka terhadap masalah yang terjadi sehingga dapat memahami dan menyelesaikan masalah, dan mampu mengaplikasikan konsep dalam situasi yang berbeda (Scriven dan Paul, 2007).

Keterampilan berpikir kritis termasuk salah satu keterampilan berpikir tingkat tinggi. Edward Glaser (Fisher, 2007) berpikir kritis merupakan kemampuan untuk: (a) mengenal masalah, (b) menemukan cara-cara yang dapat dipakai untuk menangani masalah-masalah itu, 
mengumpulkan dan menyusun informasi yang diperlukan, (d) mengenal asumsi-asumsi dan nilai-nilai yang tidak dinyatakan, (e) memahami dan menggunakan bahasa yang tepat, jelas, dan khas, (f) menganalisis data, (g) menilai fakta dan mengevaluasi pernyataan-pernyataan, (h) mengenal adanya hubungan yang logis antara masalah-masalah, (i) menarik kesimpulan-kesimpulan dan kesamaankesamaan yang diperlukan, (j) menguji kesamaan-kesamaan dan kesimpulankesimpulan yang seseorang ambil, (k) menyusun kembali pola-pola keyakinan seseorang berdasarkan pengalaman yang lebih luas; dan (1) membuat penilaian yang tepat tentang hal-hal dan kualitas-kualitas tertentu dalam kehidupan sehari-hari. Keterampilan berpikir kritis dapat dimanifestasikan dalam dua belas indikator berpikir kritis, yang dikelompokkan dalam lima kelompok keterampilan berpikir, yakni: menyimpulkan (inference), interpretasi, analisis, penjelasan, evaluasi, dan regulasi diri (self regulation) (Facione, 1990).

Penelitian-penelitian pendidikan sains mengungkapkan bahwa belajar sains merupakan suatu proses konstruktif yang menghendaki partisipasi aktif siswa (Dahar, 2011). Sejalan dengan hal itu, Jean Piaget menyatakan bahwa pengetahuan itu dibentuk sendiri oleh orang yang menggeluti suatu objek sehingga tidak dapat dipindahkan dari seorang guru ke siswa bila siswa itu sendiri tidak mau membentuknya secara aktif (Suparno, 2012). Pembelajaran kontruktivis sangat cocok dibelajarkan dalam pembelajaran kimia, siswa harus menemukan sendiri dan mentransformasikan informasi kompleks, mengecek informasi baru dengan aturan-aturan lama dan merevisinya apabila aturan itu tidak sesuai lagi. Teori kontruktivisme ini juga dapat menumbuhkan kemampuan berpikir tingkat tinggi siswa seperti keterampilan berpikir kritis, kreatif dan keterampilan proses sains siswa (Dahar, 2011). Menurut Aksela (2005) model pembelajaran yang sesuai untuk keterampilan berpikir tingkat tinggi seperti keterampilan berpikir kritis antara lain adalah pembelajaran berbasis masalah, pembelajaran inquiry, learning cycle, dan pembelajaran kooperatif. Sadia (2014) menyatakan learning cycle 7E dapat menumbuhkan serta melatihkan keterampilan berpikir kritis siswa, keterampilan berpikir kritis siswa melalui perkembangan dalam setiap fase pembelajaran.

Learning cycle merupakan model pembelajaran kontruktivisme yang dikembangkan oleh Robert Karplus dalam Science Curiculum Improvement Study (SCIS) dari Universitas California, Berkeley tahun 1970-an (Trowbright \& Bybee dalam Wena, 2009). Pada awalnya model pembelajaran learning cycle terdiri dari tiga fase dan disebut dengan learning cycle $3 \mathrm{E}$ yang terdiri dari fase ekplorasi (exploration), pengenalan konsep (concept introduction) dan aplikasi konsep (concept aplication) kemudian learning cycle $3 E$ dikembangkan menjadi learning cycle $5 \mathrm{E}$ yang terdiri dari fase engage,explore, explain, elaborate,dan evaluate (Lorsbach, 2006) dan kemudian dikembangkan lagi menjadi learning cycle $7 \mathrm{E}$ yang terdiri dari fase elicit, engage, explore, explain, elaborate, evaluate, dan extend (Eisenkraft, 2003). Menurut Karplus (1980) siklus belajar (learning cycle) dapat memperluas dan meningkatkan taraf berpikir siswa. Sejalan dengan hal itu, Sornsakda et.al, (2009) menyatakan bahwa model pembelajaran learning 
cycle 7E sangat penting dalam meningkatkan kemampuan memahami dan keterampilan berpikir kritis siswa karena pada awal pembelajaran, siswa dibimbing guru untuk menggali konsep yang sudah dipelajari kemudian dikaitkan dengan materi yang akan dipelajari.

Hasil penelitian yang menerapkan model pembelajaran learning cycle 7E diantaranya terbukti dapat menumbuhkan dan melatih keterampilan berpikir kritis siswa (Mariya, 2016 dan Yanuarti, 2013), dapat meningkatkan kemampuan literasi sains (Qulud, 2015), dapat meningkatkan penguasaan konsep dan keterampilan berpikir kritis siswa (Indrawati, dkk, 2014), dapat meningkatkan motivasi dan hasil belajar siswa (Fajaroh \& Dasna, 2004), dapat meningkatkan hasil belajar siswa (Febriana \& Arief, 2013).

Keunggulan dari model pembelajaran learning cycle 7E menurut Sadia (2014) adalah: (1) guru akan dapat memilih strategi pembelajaran yang lebih efektif, berdasarkan hasil pengungkapan pengetahuan awal siswa (elicit); (2) siswa tergugah untuk mengingat kembali terhadap materi pelajaran yag telah mereka pelajari sebelumnya; (3) melalui kegiatan engangement, siswa akan menjadi lebih aktif dan tergugah rasa ingin tahunya; (4) melalui kegiatan explorasi, siswa akan mengalami proses belajar penemuan, sehingga konsepkonsep yang dipelajari akan menjadi lebih bermakna dan tahan lama; (5) kemampuan berpikir tingkat tinggi (berpikir kritis dan berpikir kreatif) siswa akan terakomodasi dalam proses pembelajaran; (6) melalui kegiatan fase eksplanasi (explain), siswa memiliki kemampuan komunikasi ilmiah yang lebih baik; (7) melalui kegiatan pada fase extend (pengembangan), pemahaman dan penguasaan konsep siswa akan menjadi sangat kuat dan status pengetahuannya dapat mencapai status fruitfull. Meskipun demikian, menurut Sadia (2014) terdapat beberapa kelemahan dari penerapan pembelajaran berbasis learning cycle 7E, yaitu: (1) efektifitas pembelajaran rendah jika guru kurang menguasai materi dan langkah-langkah pembelajaran, menuntut kesungguhan dan kreativitas guru dalam merancang dan melaksanakan proses pembelajaran; (2) memerlukan pengelolaan kelas yang lebih terencana dan terorganisasi; (3) memerlukan waktu dan tenaga yang lebih banyak dalam menyusun rencana dan melaksanakan pembelajaran.

Berdasarkan kelemahan-kelemahan di atas maka salah satu cara untuk mengatasinya adalah dengan memanfaatkan LKS berbasis learning cycle 7E dengan bantuan weblog, karena dengan adanya bantuan weblog efektivitas pembelajaran dapat dicapai dan kegiatan penggalian konsep awal siswa serta pembangkitan minat siswa dalam pembelajaran dapat dilakukan dengan memanfaatkan multimedia untuk menampilkan simulasi-simulasi dan tampilan video yang diakses dan tersedia di weblog. Perubahan paradigma dimana Teacher-asDirector pada abad industrialisasi menjadi Teacher-as Facilitator, Guide, dan Consultant, di era pengetahuan dan teknologi merupakan hal yang wajar, karena sumber belajar dan bahan ajar tidak hanya mengadalkan dari satu sumber saja. Dampak positif dari teknologi ini dapat juga diterapkan dalam proses pembelajaran, namun harus menggunakan disain formula atau model pembelajaran yang tepat, agar hasil yang ingin dicapai dapat sesuai dengan tujuan dari proses pembelajaran di abad pengetahuan ini. 
Observasi dilakukan di salah satu SMA di kota Palangka Raya dengan jumlah sampel 80 orang (Kelas X-XII). Observasi dilakukan dengan menyebarkan angket tentang jumlah siswa yang menggunakan smartphone berbasis android dengan berbagai tipe dan merek dan pemanfaatan teknologi dalam kehidupan sehari-hari. Berdasarkan hasil observasi menyatakan bahwa terdapat $95 \%$ siswa yang menggunakan ponsel berbasis android, dan 5\% tidak mempunyai smartphone berbasis android. Selain itu, hasil observasi tentang pemanfaatan smartphone terdapat: (1) $30 \%$ siswa menggunakan ponsel untuk murni hanya untuk mencari bahan belajar atau materi pelajaran, (4) $50 \%$ bermain game, (5) $25 \%$ digunakan menonton secara streaming, mencari materi pelajaran, mendengarkan musik, (6) 5\% menggunakan untuk menyimpan data atau bahan ajar yang diberikan guru. Selain itu, hampir seluruh siswa menggunakan ponsel untuk berfoto, membuat video, media sosial, dan sisanya untuk keperluan lain.

Berdasarkan hasil observasi tersebut ternyata ponsel berbasis android masih belum dimanfaatkan sebagaimana mestinya untuk pembelajaran. Oleh karena itu, weblog sangat cocok untuk dimanfaatkan dalam pembelajaran kimia menggunakan ponsel berbasis android dengan keadaan seperti hasil observasi. Pemanfaatan weblog dalam pembelajaran kimia merupakan salah satu solusi dalam membantu siswa lebih memahami materi pelajaran yang disampaikan. Pembelajaran dengan bantuan weblog memiliki beberapa kelebihan yaitu menggalakan proses belajar induktif, mewujudkan pengalaman dan keputusan yang nyata serta membiasakan pembelajar berpikir kritis (Maddux et. al. dalam Munir, 2012). Dengan adanya weblog pembelajaran siswa dapat mengulangulang kembali pelajaran yang telah dilakukan di kelas kapan saja dan dimana saja tanpa dibatasi oleh waktu dan tempat dengan menggunakan jaringan internet untuk mengakses website pembelajaran. Pembelajaran melalui internet menurut Bates (dalam Munir, 2012) (1) dapat meningkatkan kadar interaksi pembelajaran antara siswa dan guru, (2) memungkinkan terjadinya interaksi pembelajaran darimana dan kapan saja, (3) menjangkau siswa dalam cakupan yang luas, (4) Mempermudah penyempurnaan dan penyimpanan materi pembelajaran. Fungsi internet sebagai media pembelajaran dapat berupa sebagai komplemen (pelengkap), suplemen (tambahan) dan substitusi (pengganti). Dalam penelitian ini fungsi weblog untuk pembelajaran hanya sebagai pelengkap dan suplemen, yang mana membantu siswa untuk memahami pembelajaran secara menyeluruh melalui pengamatan langsung maupun tidak langsung.

Rumusan masalah dalam penelitian ini adalah apakah pembelajaran menggunakan LKS berbasis learning cycle 7E berbantuan weblog dapat melatih keterampilan berpikir kritis dan motivasi belajar siswa. Penelitian ini bertujuan mendeskripsikan peningkatan keterampilan berpikir kritis siswa pada materi asam basa menggunakan LKS berbasis learning cycle $7 E$ serta motivasi belajar siswa.

\section{METODOLOGI PENELITIAN}

Penelitian ini menggunakan metode pre-experimental dengan desain penelitian one group pretest-posttest. Penelitian dilaksanakan di salah satu SMA di Kota Palangka Raya pada semester II Tahun Pelajaran 2017/2018. Subjek dalam penelitian ini adalah 
siswa kelas XI IPA. Untuk pengumpulan data menggunakan instrumen soal tes bentuk uraian. Soal tes berisi item-item soal yang bertujuan untuk mengukur penguasaan konsep pada materi asam basa dan keterampilan berpikir kritis baik sebelum (pretest) atau setelah implementasi pembelajaran (posttest). Hasil pre-test dan posttest diolah dan dianalisis untuk mengetahui peningkatan penguasaan konsep dan keterampilan berpikir kritis siswa.

Penguasaan konsep dan keterampilan berpikir kritis (KBK) dianalisis dengan menggunakan gain score (skor peningkatan). Besarnya gain score dianalisis menggunakan rumus Hake (1998).

$$
\frac{\mathrm{S}_{\mathrm{f}}-\mathrm{S}_{\mathrm{i}}}{100-\mathrm{S}_{\mathrm{i}}} \ldots \ldots \ldots \ldots
$$

Keterangan:

$$
\begin{array}{ll}
\langle\mathrm{g}\rangle & =\text { gain yang dinormalisasi } \\
\mathrm{S}_{\mathrm{f}} & =\text { skor post-test } \\
\mathrm{Si} & =\text { skor } \text { pre-test } \\
100 & =\text { skor maksimum }
\end{array}
$$

Hasil perhitungan gain score tersebut kemudian dimaknai menggunakan acuan yang dikemukakan oleh Hake (1998) pada Tabel 2. label konsep. Gambar 2 menunjukkan terjadi peningkatan penguasaan konsep pada semua label konsep. Peningkatan penguasaan konsep tertinggi pada subkonsep hubungan kekuatan asam/basa dengan derajat ioniasi $(\alpha)$ dan $\mathrm{K}_{\mathrm{a}} / \mathrm{K}_{\mathrm{b}}$ dengan nilai gain score 0,96 dan yang terendah pada konsep mengindentifikasi $\mathrm{pH}$ melalui percobaan dengan gain score 0,65.

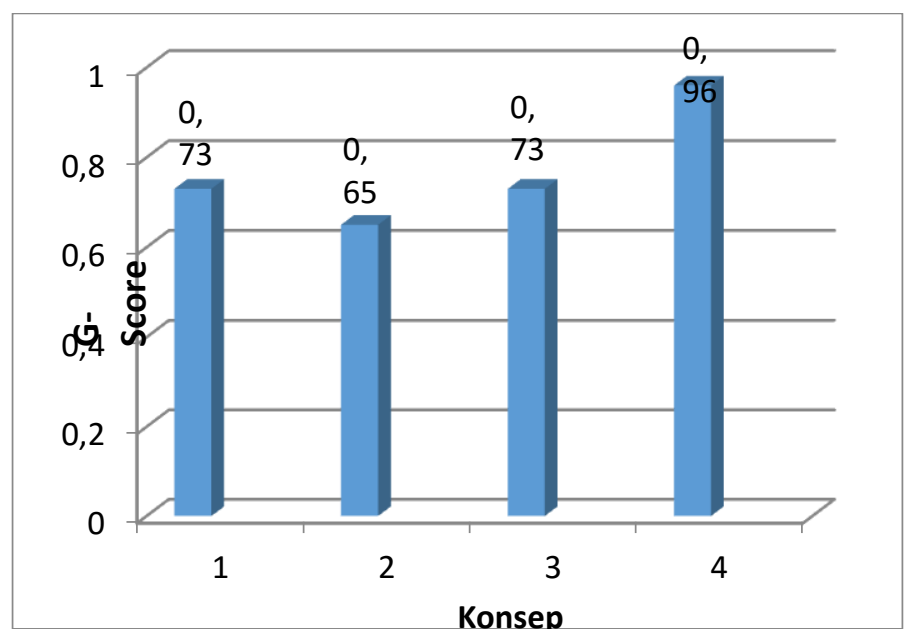

\section{Gambar 2. Nilai Gain Score pada Setiap Konsep}

Keterangan:

1 : Teori / Konsep Asam dan Basa

2 : Mengidentifikasi $\mathrm{pH}$ larutan melalui percobaan

3 : Kesetimbangan asam/basa pada kesetimbangan air $\left(\mathrm{K}_{\mathrm{w}}\right)$

4 : Hubungan kekuatan asam / basa dengan derajat ioniasi $(\alpha)$ dan $\mathrm{K}$

Tabel 2. Kriteria Tingkat Gain

\begin{tabular}{c}
\hline$\langle\mathrm{g}>$ \\
$\mathrm{g}>0,7$ \\
$0,3 \leq \mathrm{g}<0,7$ \\
$\mathrm{~g}<0,3$ \\
\hline (Diadaptasi dari Hake, 1998)
\end{tabular}

\section{HASIL PENELITIAN DAN PEMBAHASAN}

Data yang diperoleh dari hasil penelitian ini adalah nilai penguasaan konsep atau hasil belajar siswa dan nilai kemampuan berpikir kritis (KBK). Secara umum siswa mengalami peningkatan penguasaan konsep dengan gain score 0,76 , dengan kriteria tinggi. Pembelajaran asam basa terdiri dari 4
Indikater keterampilan berpikir

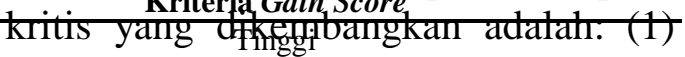
Evaluasi, stallang (2) Penjelasan. Penggunaan Renja herbasis learning cycle 7E berbantuan weblog pada pembelajaran asam basa dapat meningkatkan keterampilan berpikir kritis (KBK) seperti yang terlihat pada Gambar 3. Keterampilan berpikir kritis yang dikembangkan semua dikuasai dengan kriteria gains score tinggi. 


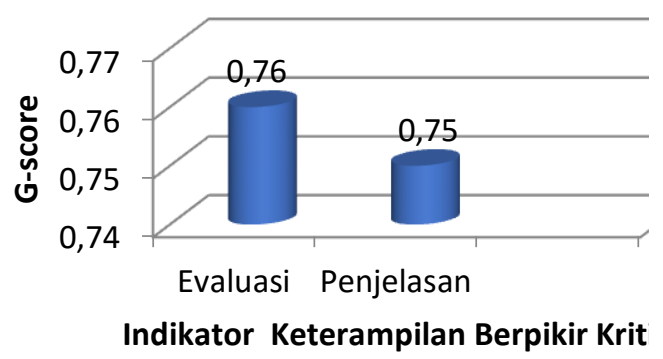

Gambar 3. Grafik G-score pada Setiap Keterampilan Berpikir Kritis (KBK)

Peningkatan penguasaan konsep dalam setiap konsep pembelajaran disebabkan pada setiap fase pembelajaran menggunakan LKS berbasis LC 7E ini dapat memunculkan keterampilan berpikir kritis siswa. Melalui pembelajaran menggunakan LKS berbasis LC 7E dengan bantuan weblog siswa dapat belajar mengetahui (learning to know) dan belajar berbuat/berkarya (learning to $d o$ ). Hal ini disebabkan adanya pemanfaatan teknologi dalam pembelajaran, memungkinkan sejumlah besar informasi dan pengetahuan yang tersimpan bisa didapatkan dengan mudah hanya dengan membuka situs atau alamat weblog yang diinginkan. Pengelolaan siswa terhadap penguasaan dan pemanfaatan informasi melalui weblog dengan model learning cycle 7E mulai dari membaca, mengakses internet, dan menerapkan konsep yang telah didapat dalam keadaan nyata untuk menyelesaikan permasalahan yang terkait dengan kasus yang ada. Secara tidak langsung, kemungkinan keterampilan berpikir kritis yang lain dapat dilatihkan. Saat mengakses internet, siswa juga belajar memilah informasi yang penting dan tidak penting, sehingga kemampuan literasi informasi siswa juga secara tidak langsung mulai dilatihkan. Jika keadaan ini terus dilakukan maka pembelajaran 4.0 akan mengarah ke hal positif.

Pembelajaran menggunakan LKS berbasis LC 7E dengan bantuan weblog dapat mengajarkan siswa tentang prinsip belajar menjadi diri sendiri secara utuh (learning to be), yang mana siswa dapat berlatih memilah informasi yang ingin didapat melalui informasi yang tertera pada weblog. Aspek intelektual, sosial maupun moral serta dalam proses pembelajaran siswa dilatih untuk berkolaborasi dengan teman-teman dalam kelompok kecil. Pemanfaatan internet menuntut siswa untuk sadar keperluan utama yang ingin dicari dan bertanggung jawab tentang informasi yang ingin dan telah didapatkan. Tidak hanya keterampilan berpikir kritis yang terlatih, kemampuan literasi digital siswa mulai terasah dalam pemanfaatan weblog.

Aktivitas siswa pada fase-fase learning cycle 7E seperti menjawab pertanyaan pada LKS diperlengkapi dengan beberapa ilustrasi yang ada di weblog, bertujuan untuk mengingat pengetahuan sebelumnya (fase elicit), aktivitas siswa saat mendefinisikan masalah mengenai keterkaitan antara pembelajaran yang lalu dengan materi yang akan dipelajari dengan menjawab soal pada LKS atau membaca kajian literatur dari sumber lain (fase engange), aktivitas siswa saat melakukan percobaan sesuai prosedur, melakukan pengamatan dengan mencatat hasil pengamatan, menjawab pertanyaan pada LKS yang berindikator keterampilan evaluasi dan penjelasan (fase explore), aktivitas siswa mempresentasikan hasil diskusi kelompok dan memberikan masukan ide saat proses diskusi (fase explain), aktivitas siswa meneyelasaikan soal berupa aplikasi konsep berindikator evaluasi dan penjelasan (fase elaborate), aktivitas siswa 
menyelesaikan soal yang sesuai dengan indikator pembelajaran (fase evaluate), dan aktivitas siswa menjawab pertanyaan aplikasi konsep dalam kehidupan sehari-hari berindikator keterampilan evaluasi dan penjelasan (fase extend).

Pada fase extend, keterampilan berpikir kritis siswa semakin dilatih dan dipertajam, khususnya untuk indikator KBK penjelasan. Siswa mulai melakukan analisis, mengevaluasi hasil analisis kemudian menarik kesimpulan. Kegiatan tersebut dilakukan untuk membenarkan atau mengklarifikasi penalaran atau pernyataan yang bersifat konseptual dan kontekstual. Hal ini juga terjadi pada indikator KBK evaluasi, kemampuan siswa untuk melakukan evaluasi atau penilaian mengenai suatu pernyataan ataupun hasil yang diperoleh pada kegiatan diskusi atau percobaan (fase elaborate, explain dan evaluate). Seperti halnya penjelasan, evaluasi digunakan di saat menarik kesimpulan. Menghubungkan beberapa variabel dan kesesuaian antarvariabel sehingga didapatkan suatu kesimpulan. Evaluasi dilakukan dengan cara representasi yaitu dengan menangkap objek berupa data dan deskripsi melalui mata atau visual. Evaluasi dilakukan juga dengan menaksir pernyataan, yaitu dengan cara mengira, menjelaskan cara-cara untuk menilai anggapan benar atau tidak untuk menarik kesimpulan.

Setiap fase dalam pembelajaran learning cycle 7E memungkinkan untuk melatih beberapa keterampilan berpikir kritis. Hanya saja yang lebih ditekankan adalah KBK evaluasi dan penjelasan. Keterampilan ini diperlukan agar siswa dapat menarik kesimpulan yang tepat serta dapat membuat interpretasi yang sesuai dengan data yang benar. Secara garis besar, LKS berbasis learning cycle 7E dengan bantuan weblog dapat menumbuhkan serta melatihkan keterampilan berpikir kritis siswa. Pengetahuan konseptual, prosedural dan prinsip dapat dilatihkan dalam melalui LKS berbasis learning cycle 7E dengan bantuan weblog. Siswa dapat membuka blog di mana pun mereka ingin belajar dan melatih kemampuan literasi digital siswa. Menurut teori Vygotsky, perkembangan kognitif seseorang tidak hanya dipengaruhi oleh faktor internal (faktor biologis) tetapi juga faktor eksternal seperti lingkungan (Trianto, 2009). Hal ini dikarenakan konstruksi pengetahuan akan terjadi saat adanya interaksi dengan orang lain, seperti guru daan siswa atau siswa dengan siswa, siswa dengan sumber belajarnya termasuk LKS dan weblog yang digunakan. Selama kegiatan pembelajaran berlangsung siswa dapat bertukar ide, saling membuktikan dan mengklarifikasi jawaban sehingga dihasilkan pengetahuan yang baru. Selain itu, siswa dapat saling membantu mengkonstruk pengetahuan dan bekerja sama untuk mencapai tujuan pembelajaran. Guru hanya berperan sebagai pembimbing dan motivator bagi siswanya.

Secara inferensial pembelajaran menggunakan LKS berbasis learning cycle 7E berbantuan weblog sangat relevan dengan tujuan Kurikulum 2013 dan berdampak positif terhadap penguasaan konsep siswa serta keterampilan berpikir kritis siswa. Hal ini didukung dengan hasil wawancara tidak terstruktur dengan beberapa siswa dengan kategori siswa memiliki skor tinggi, sedang dan rendah. Siswa yang memiliki skor rendah menyatakan bahwa belajar menggunakan LKS berbasis learning cycle $7 \mathrm{E}$ dengan bantuan weblog sangat baru bagi mereka dan mereka merasa bahwa di dalam proses pembelajaran dilibatkan secara langsung dalam pembelajaran dan menemukan konsep sendiri. Selain 
itu, mereka menemukan konsep baru tentang penyebab air yang seharusnya netral bisa bersifat asam seperti air gambut yang ada di Kalimantan Tengah. Konsep belajar bermakna yang berkaitan dengan kehidupan sehari-hari membuat siswa bersemangat untuk belajar. Belajar dengan weblog membuat mereka bisa belajar dimana saja, tinggal ketik alamat blognya untuk mencari materi yang ingin dibaca. Konsep yang disajikan dalam LKS dan weblog sangat mudah dipahami, dilengkapi dengan beberapa contoh soal yang memfasilitasi dalam pengerjaan LKS.

Siswa dengan skor tinggi menyatakan LKS berbasis learning cycle 7E dengan bantuan weblog sangat bermanfaat, karena konsep yang dipelajari berangkat dari konsep prasyarat dan hal-hal sederhana dalam kehidupan sehari-hari, kemudian perlahan-lahan naik ke konsep yang lebih kompleks dan kemudian dihubungkan dalam kehidupan seharihari. Sehingga saat belajar mereka merasa tidak terkejut karena dalam pembelajaran mereka dituntun memahami konsepnya dari dasar dan sederhana. Pengalaman yang mereka temukan dalam kehidupan sehari-hari dapat mereka kaitkan dengan materi pembelajaran yang mereka pelajari saat itu. Selain itu, siswa berpendapat bahwa dengan belajar melalui blog, mereka dapat membuka materi yang telah dipelajari untuk diulang dan dibaca lagi, karena bersifat digital maka penggunaan kertas menjadi berkurang dan lebih hemat. Literasi yang muncul tidak hanya literasi membaca, menulis, matematika dan sains namun literasi digital dan literasi informasi juga dimunculkan, sehingga terjadi peningkatan kemampuan membaca, menganalisis, dan menggunakan informasi di dunia digital (Big Data).
Hal ini sejalan dengan yang diungkapkan Mecit (2006), model learning cycle 7E dapat meningkatkan keterampilan berpikir kritis siswa secara signifikan dibandingkan dengan metode tradisional, perbedaan jenis kelamin siswa dan pendapatan keluarga tidak mempengaruhi keterampilan berpikir kritis siswa dan penguasaan konsep. Learning cycle adalah model pembelajaran yang efektif untuk sains dan sangat dikenal oleh para pengajar sains. Pemanfaatan teknologi informasi dalam pembelajaran sangat diperlukan untuk melatih siswa menghadapi tantangan abad 21 dan era revolusi industri 4.0. Penerapan pembelajaran menggunakan model pembelajaran yang bervariasi yang dipadu dengan pemanfaatan teknologi informasi di antaranya pemanfaatan weblog dapat meningkatkan kemandirian siswa dalam belajar (self training skill) agar dapat ikut berpartisipasi dalam proses pengambilan keputusan sesuai dengan tujuannya. Diharapkan dengan keterampilan berpikir kritis yang terlatih dan mumpuni, siswa dapat bersaing jaman globalisasi dan meningkatkan kemampuannya agar tidak tersingkir oleh kemajuan jaman.

\section{SIMPULAN}

Berdasarkan dari hasil analisis yang telah dipaparkan di atas pembelajaran asam basa menggunakan LKS berbasis learning cycle 7E berbantuan weblog dapat melatih dan meningkatkan keterampilan berpikir kritis siswa. Konsep yang paling dikuasai siswa setelah belajar menggunakan LKS berbasis learning cycle $7 E$ dengan bantuan weblog adalah tentang konsep hubungan kekuatan asam / basa dengan derajat ioniasi $(\alpha)$ dan $\mathrm{K}_{\mathrm{a}} / \mathrm{K}_{\mathrm{b}}$ dengan rata-rata $\mathrm{N}$-Gain 0,96. Indikator keterampilan berpikir kritis yang dikuasai siswa adalah 
evaluasi dan penjelasan dengan kriteria gain score tinggi. Siswa memberikan tanggapan yang baik terhadap pembelajaran menggunakan LKS berbasis learning cycle $7 E$ dengan bantuan weblog, karena pembelajaran mengaitkan kejadian yang ada dalam kehidupan sehari-hari serta kemudahan mengakses informasi weblog dimanapun dan kapanpun.

Penerapan

pembelajaran menggunakan model pembelajaran yang bervariasi yang dipadu dengan weblog dapat meningkatkan kemandirian siswa dalam belajar (self training skill), sehingga pembelajaran menggunakan teknologi dan informasi harus diperhitungkan dalam pembelajaran modern, sehingga keterampilan abad 21 termasuk di antaranya keterampilan berpikir kritis dapat ditingkatkan dan dibiasakan dalam menghadapi tantangan di dunia global sekarang. Selama proses pembelajaran, perlu membangun karakter siswa melewati pembekalan tentang pemilahan informasi yang benar sesuai dengan konteks pembelajaran yang sedang dijalani agar informasi yang didapatkan dan disajikan kelak memiliki keabsahan dan tidak salah tafsir.

\section{DAFTAR PUSTAKA}

Aksela, M. (2005). Supporting meaningful chemistry learning and higher order thinking through computer-assited inquiry: a design research approach.

Dahar, R.W. (2011).Teori-Teori

Belajar. Jakarta: Erlangga

Facione. (1990). Critical Thinking: A Statement of Expert Consensus for Purposesof Educational Assessment and Instruction. California: Santa Clara University. (ERIC Document Reproduction Service)
Fajaroh, F. \& Dasna, I.W. (2005). Penggunaan Model Pembelajaran Learning Cycle Untuk Meningkatkan Motivasi Belajar Dan Hasil Belajar Kimia Zat Adiktif Dalam Bahan Makanan Pada Siswa Kelas I SMU Negeri 1 Tumpang Malang. Jurnal Pendidikan dan Pembelajaran, 11(2), hlm. 112122

Fajaroh dan Dasna. (2009). Pembelajaran Dengan Model Siklus Belajar (Learning Cycle). (Online).(http://sahaka.multiply.c om/journal/item/29/pembelajarandengan_model_siklus_belajar_lea rning_cycle). Diakses 1 Mei 2017

Fisher, Alec. (2007). Berpikir Kritis Sebuah Pengantar. Terjemahan oleh Benyamin Hadinata. Jakarta: Erlangga

Hake, R.R. (1998). Interactiveengangement versus tradisional methods: A Sis-thousand-student Survey of Mechanics Test Data for Introductory physics course. America: The American Journal of Physics Teacher

Kemendikbud. (2013). Pergeseran Paradigma Belajar Abad 21, Badan Penelitian dan Pengembangan, Kementrian Pendidikan dan Kebudayaan. (Online).

http://litbang.kemdikbud.go.id/site/ index.php/home2-4/233-

pergeseran-paradigma-belajarabad-21. Diakses 15 Oktober 2018. Kemendikbud. Penyelenggaraan Pendidikan Sistem Ganda pada Sekolah Menengah Kejuruan.Jakarta: Direktorat Pendidikan Menengah Kejuruan.

Kemendikbud. No.0490/U/1992. Sekolah Menengah Kejuruan. Jakarta: Departemen Pendidikan dan Kebudayaan 
Liliasari. (2002). Pengembangan Model Pembelajaran Kimia untuk Meningkatkan Strategi Kognitif Mahasiswa Calon Guru dalam Menerapkan Berpikir konseptual Tingkat Tinggi. Laporan Penelitian Hibah Bersaing IX Perguruan Tinggi Tahun Anggaran 2001-2002. Bandung: FMIPA UPI.

Lorsbach, A. W. (2002). The Learning Cycle As A Tool For Planning Sience Instruction. (Online). Tersedia di: http://www.coe.ilstu.edu/scienceed/ Lorsbach2571rcy.htm. Diakses 15 Oktober 2018.

Liliasari. (2002). Pengembangan Model Pembelajaran Kimia untuk Meningkatkan Strategi Kognitif Mahasiswa Calon Guru dalam Menerapkan Berpikir konseptual Tingkat Tinggi. Laporan Penelitian Hibah Bersaing IX Perguruan Tinggi Tahun Anggaran 20012002. Bandung: FMIPA UPI.

Lorsbach, Anthony W. (2008). The Learning Cycle as a Tool for Planning Science Instruction. Illinois State University. (Online), (http://www.coe.ilstu.edu/science ed/lorsbach/257lrcy.htm), diakses 2 Mei 2017.

Mariya, Lika. (2016). Pengembangan lembar kerja peserta didik (LKPD) Learning Cycle 7-E Materi Pemanasan Global Untuk Menumbuhkan Keterampilan Berpikir Kritis Siswa. Tesis. Universitas Bandar Lampung. (Online), (snfunj.ac.id/index.php/download_file /view/462/185/pdf). Diakses 2 Mei 2017.

Mecit, O. (2006). "The Effect of $7 E$ Learning Cycle Model on The Improvement of Fifth Grade
Students' Critical Thinking Skills". Doctoral Dissertation, Middle East Technical University.

Mukhadis, Amat. (2013). Sosok Manusia Indonesia Unggul dan Berkarakter dalam Bidang Teknologi Sebagai Tuntutan Hidup di Era Globalisasi.(online), (http://journal.uny.ac.id/index.php /jpka/article/view/1434), diakses tanggal 11 Oktober 2018.

Munir, (2012). Multimedia Konsep Dan Aplikasi Dalam Pendidikan. Bandung: Alfabeta

Qulud, dkk. (2015). Penerapan Model Pembelajaran Learning Cycle 7E untuk Meningkatkan Kemampuan Literasi Sains Siswa Pada Konsep Sistem Reproduksi Kelas XI Di SMA Negeri 1 Arjawinangun. Scientiae Educatia Volume 5 Nomor 1 Tahun 2015.

Sadia, I Wayan. (2014). Model-model Pembelajaran Sains Konstruktivistik. Yogyakarta: Graha Ilmu

Scriven, M., \& Paul, R. (2007). Defining Critical Thinking. The Critical Thinking Community: Foundation for Critical Thinking. (Online).Tersedia di: http://www.criticalthinking.org/ab outCT/define_critical_thinking.cf m. Diakses 15 September 2018

Sornsakda, S., Suksringarm, P., \& Singseewo, A. (2009). Effects of Learning Environmental Education Using the 7E-Learning Cycle with Metacognitive Technique and Theachers Handbook Approaches on Learning Achievment, Integrated Science Process Skills and Critical Thinking of Mathayomsuksa 5 Students with Different Learning Achievment. 
Pakistan Journal of Social

Sciences. 6 (5), hlm. 297-303

Wena, M. (2009). Strategi

Pembelajaran Inovatif

Kontemporer. Jakarta: Bumi

Aksara

Yanuarti, Nourma Rosalina dan Azizah,

Utiya. (2013). Pengembangan

Lembar Kegiatan Siswa

Berorientasi Learning Cycle 7-E

pada Materi Pokok

Kesetimbangan Kimia untuk

Melatih Keterampilan Berpikir

Kritis. Unesa Journal of Chemical

Education, Vol. 2, No. 2, pp. 32-

38 May 2013, ISSN: 2252-9454 